a syndrome of " simple bronchitis" (in effect chronic phlegmproduction) was equally common in Berlin and Britain, the complex syndrome, also involving breathlessness and repeated chest illness, was much more frequent in the British population, particularly in men aged 55 and over. Although women display similar trends, the differences, like the differences in female British and American death rates from chronic respiratory disease, are not nearly so dramatic.

In general, the trends in the results, in terms of averages, of the application of the peak-flow meter test agree with the general impression of more severe disease in the older British male; but the evidence is slender. More serious impairment, however, is clearly commoner in the British male group. Indeed, all these results underline the fact that it is at the extremes of the range of respiratory function that the difference between two populations is most readily detected.

It is tempting to speculate on the explanation of these tentative findings. The placing of this one American town in relation to the rural-urban gradient in British experience and the rather higher rates of disease in British non-smokers might suggest that some factor in British urban life, such as air pollution, was accentuating the effect of smoking on respiratory malfunction. This preliminary inquiry cannot suggest the nature of that factor with any precision, for no account has been taken of the social-class background which appears so decisively in sickness and death rates from bronchitis in Britain. It has, however, demonstrated the potential of such comparisons and emphasized the need for their wider and more sophisticated application.

\section{Summary}

The reported British excess in bronchitic morbidity has been studied by comparing the results of field surveys carried out in various parts of this country and in one town in the United States. In both, similar respiratory-symptom questionaries and a simple lung-function test (the Wright peak-flow meter) were used.
The prevalence of "simple bronchitis"-that is, chronic phlegm-production-differs little between the American towns and the rural and urban areas of Britain; and its relation to cigarette smoking in particular is obvious in the results from both countries. On the other hand, "complex bronchitis" with repeated chest illnesses and breathlessness is more common among older men in this country. After differences in age distribution and smoking habits have been taken into account, this form of bronchitis appears to be about equally common in the American town and in the rural areas of Britain. It is much more common, however, in the British towns and cities, especially among men.

The results of the lung-function test are consistent with this suggestion of a higher prevalence of a more severe form of bronchitis among older males living in British urban conditions. The causes of this excess are still uncertain.

This investigation was supported in whole by U.S. Public Health Service Grant HE 04775-03 from the National Heart Institute. The original studies were supported by the Dominion of Canada National Health Research Grant (Project No. 609-7-73), the United States Public Health Service Research Grant (OH-67), and the Nuffield Provincial Hospitals Trust. The College of General Practitioners has kindly allowed us to use the data collected by members of their College for the Respiratory Diseases Study Group. We are indebted to Miss Elizabeth Farrow for the computations involved.

\section{REFERENCES}

Anderson, D. O., and Ferris, B. G. (1962). New Engl. F. Med., 267, 787. College of General Practitioners (1961). Brit. med. F., 2, 973. Ferris, B. G., and Anderson, D. O. (1962). Amer. Rev. resp. Dis., 86, 165.

Fletcher, C. M., Elmes, P. C., Fairbairn, A. S., and Wood, C. H. (1959). Brit. med. $7 ., 2,257$.

Hammond, E. C., and Garfinkel, L. (1961). 7. nat. Cancer Inst., 27, 419. Higgins, I. T. T. (1957). Brit. med. f., 2, 1198.

Meneely, G. R., Paul, O., Dorn, H. F., and Harrison, T. R. (1960). F. Amer. med. Ass., 174, 1628.
Ameely, G. R., Paul, O., Dorn,

Olsen, H. C., and Gilson, J. C. (1960). Brit. med. f., 1, 450.

Reid, D.'D.' (1960). Amer. 7. publ. Hlth, 50, 53

Todd, G. F. (1963). Research Paper No. 6. Tobacco Research Council, London.

\title{
Comparison of Lymecycline with Tetracycline Hydrochloride
}

\author{
J. L. WHITBY,* M.B., M.R.C.P., M.C.PATH. ; H. J. BLACK,* M.B., B.CH.
}

Brit. med. F., 1964, 2, 1491-1495

Lymecycline (tetracycline-L-methylenelysine ; Tetralysal) is a tetracycline-amino-acid compound obtained by combining tetracycline base with L-lysine in the presence of formaldehyde. Its formula (de Carneri and Manfredi, 1962) gives a molecular weight for the pure substance of 602.7 , while the molecular weight of tetracycline hydrochloride is 480.9 and the drugs are equivalated in this ratio. It may have certain advantages over tetracycline hydrochloride in that its solubility, particularly in water, is much greater than that of other tetracyclines (de Carneri et al., 1961), and it has been claimed that it is absorbed more completely than tetracycline hydrochloride from the gastro-intestinal tract. It is also suitable for intramuscular injection. We here report the results of a clinical trial of this compound. In this trial blood levels after oral lymecycline were compared with those following tetracycline hydrochloride and

* From the Department of Clinical Pathology, Queen Elizabeth Hospital, Birmingham. the incidence of side-effects in patients after the use of these drugs was also compared.

\section{Materials and Methods}

Antibiotics. - Tetracycline hydrochloride B.P. as obtained from the pharmacy of the Queen Elizabeth Hospital was used as a reference standard. A preparation of lymecycline powder was supplied by Messrs. Carlo Erba ; biological assay in Italy of their preparation had shown $1 \mathrm{~g}$. of the lymecycline powder to be equivalent to $0.6056 \mathrm{~g}$. of tetracycline base or $0.6553 \mathrm{~g}$. of tetracycline hydrochloride. From these materials standards were made up for antibiotic assays throughout the trial.

Antibiotic assays were performed by a cylinder-plate method in the following manner. A measured $6 \mathrm{ml}$. of nutrient agar was added to $9-\mathrm{cm}$. disposable plastic Petri dishes which were 
stood on a level bench until set. A measured $4 \mathrm{ml}$. of preinoculated agar was then poured on top of the lower agar layer in the Petri dishes and when set six vitreous porcelain cups $7.5 \mathrm{~mm}$. in diameter were sealed on to the surface $2.5 \mathrm{~cm}$. apart and $2.5 \mathrm{~cm}$. from the centre. Standard curves were plotted and dilutions of sera for assay were randomized and assayed in quadruplicate; two standards were included on each plate.

The test organism used was the Oxford strain of Staphylococcus aureus. This strain gives satisfactory zones for tetracycline assays down to levels of $0.1 \mu \mathrm{g} . / \mathrm{ml}$. as compared with Bacillus cereus, which can be used to assay levels as low as $0.025 \mu \mathrm{g} . / \mathrm{ml}$. The staphylococcus was chosen because in our hands the inhibition zones were sharp and easily measured and the antibiotic levels were well within the range of the assay.

Minimum inhibitory concentrations of lymecycline and tetracycline hydrochloride for various organisms were determined in the following manner. Serial dilutions of the antibiotics were made in broth and $0.02 \mathrm{ml}$. of an overnight broth culture of the test organisms was added. This inoculum was the same as the large inoculum used by Bond et al. (1963) in their comparisons of phenoxypenicillins.

Clinical Trial.-The two drugs were directly compared by a blind trial for which indistinguishable capsules were supplied by Messrs. Fraser Chemicals Ltd. The capsules used were subsequently assayed for tetracycline content to verify that they contained the specified amount of antibiotic. At the start of the trial all supplies of tetracycline in the wards concerned were removed and replaced by one or other of the trial capsules. The capsules in use in any ward were known only to the hospital pharmacist. During the course of the trial the drugs in use were changed, the changes made being also known only to the pharmacist. All patients in the wards for whom tetracycline was prescribed were given trial material regardless of whether they were being treated simultaneously with other antibiotics, but only those who had a tetracycline compound alone were included in the analysis of the trial. At the end of the course of tetracycline or lymecycline a questionary was completed indicating the reasons for therapy, the dose, the clinical response, and asking specific questions about side-effects. From some of these ward patients, at random, samples of blood were taken at known times after a dose, and antibiotic levels were determined. For these determinations comparisons were made with tetracycline hydrochloride standards alone.

\section{Comparison of the Properties of Lymecycline and Tetracycline Hydrochloride}

Initial assays of tetracycline hydrochloride and lymecycline were performed by the cylinder-plate method as described.

The standards were prepared by weight from powdered tetracycline hydrochloride and powdered lymecycline. For the latter $1 \mathrm{~g}$. was taken to equal $605.6 \mathrm{mg}$. of tetracycline base $(655.3 \mathrm{mg}$. of tetracycline hydrochloride) as stated by the manufacturers. When this correction was made for equivalence in the lymecycline preparation the diffusion zones for comparable solutions of the two compounds were identical over the assay range, whether the solutions were made up in buffer, horse serum, or human serum (Fig. 1), although the slope for the assay of both compounds was steeper using serum standards, which is accounted for by protein-binding. Antibacterial activity is not greatly affected by the conjugation, and M.I.C. determinations with a wide variety of strains of different bacterial species showed little difference in the M.I.C. of tetracycline hydrochloride and lymecycline (Table I). This accords with the results of de Carneri et al. (1961), who found no difference in activity between the two compounds for the 12 bacterial species they tested. In our results a single strain of Staph. aureus showed a difference of sensitivity of two tubes, otherwise results never differed by more than one tube in either direction, and for the Oxford Staphylococcus-the assay strain -antibiotic activity was identical.

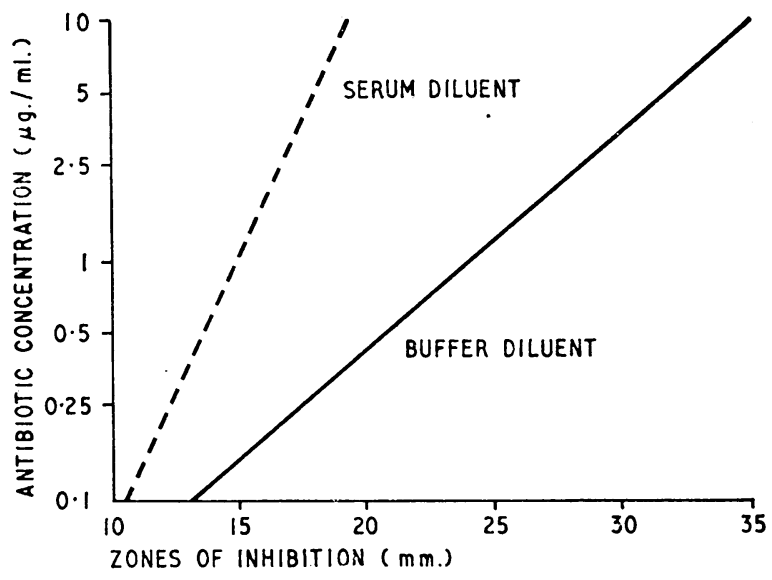

FIG. 1.-Cylinder plate method. The inhibition of Staph. aureus produced by standard solutions of tetracycline hydrochloride and lymecycline in phosphate buffer $p H 4.5$ and pooled human serum. The curves for tetracycline hydro chloride and lymecycline were coincident.

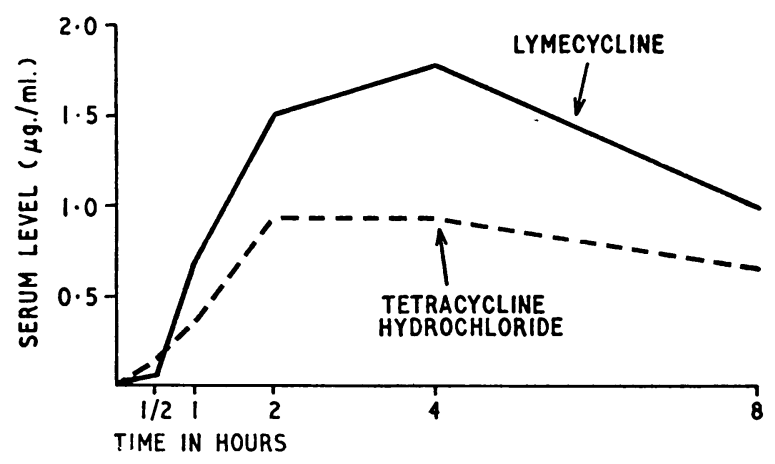

FIG. 2.-Mean serum levels after a single oral dose of tetracycline hydrochloride ( $250 \mathrm{mg}$.) and lymecycline (equivalent to $162 \mathrm{mg}$. of tetracycline hydrochloride) in six volunteers. (Values expressed as $\mu \mathrm{g}$. of tetracycline hydrochloride per ml.)

TABLE I.-Minimum Inhibitory Concentrations of Tetracycline Hydrochloride and Lymecycline

\begin{tabular}{|c|c|c|c|c|}
\hline & & $\begin{array}{c}\text { No. of } \\
\text { Strains Tested }\end{array}$ & $\begin{array}{l}\text { Tetracycline } \\
\text { Hydrochloride }\end{array}$ & Lymecycline \\
\hline 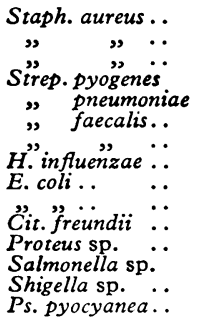 & $\begin{array}{l}\because \\
\therefore \\
\therefore \\
\therefore \\
\therefore \\
\therefore \\
\therefore \\
\therefore \\
\therefore \\
\therefore\end{array}$ & $\begin{array}{c}\text { (Oxford) } \\
4 \\
4 \\
7 \\
2 \\
2 \\
22 \\
8 \\
3 \\
1 \\
1 \\
7 \\
3 \\
3 \\
1\end{array}$ & $\begin{array}{c}0 \cdot 12 \\
0 \cdot 12-1 \cdot 0 \\
256-512 \\
0 \cdot 06-1 \\
0 \cdot 12-0 \cdot 25 \\
1-4 \\
32-256 \\
0 \cdot 12-0 \cdot 5 \\
1-2 \\
>128 \\
>64 \\
32-128 \\
0 \cdot 5-2 \\
1-2 \\
>64\end{array}$ & $\begin{array}{c}0 \cdot 12 \\
0 \cdot 12-0 \cdot 25 \\
256 \\
0 \cdot 12-2 \\
0 \cdot 12-0 \cdot 25 \\
0 \cdot 5-4 \\
16-256 \\
0 \cdot 25-0 \cdot 5 \\
1-2 \\
>128 \\
>64 \\
32-64 \\
0 \cdot 5-2 \\
1-2 \\
>64\end{array}$ \\
\hline
\end{tabular}

Values expressed as $\mu \mathrm{g}$. of tetracycline hydrochloride per ml.

We determined the minimum inhibitory concentration for a large number of strains of Streptococcus faecalis, as this organism is usually regarded as sensitive to the tetracyclines (Barber and Garrod, 1963). In our experience many strains of Str. faecalis isolated from routine clinical material are now tetracycline-resistant, and this proved to be so. Such strans were also found to be resistant to lymecycline.

The similarity of lymecycline to tetracycline hydrochloride in antibacterial behaviour is important, for it is believed that in the body lymecycline slowly dissociates into its two constituent parts (Cambiaghi, to be published) and thus at anr time the tetracycline activity detectable in the serum or body 
fluids will be due to both undissociated lymecycline and to tetracycline base. If these two compounds behaved differently microbiological assay methods would be meaningless and satisfactory determinations of blood antibiotic levels very difficult to perform.

To compare the absorption of these two compounds they were given on separate occasions to six members of the hospital pharmacy staff-four females and two males. The drugs were taken by mouth in identical capsules at 9.30 a.m., between one and one and a half hours after breakfast.

Tables II and III show the blood levels obtained in these volunteers. The dose of lymecycline was equivalent to $162 \mathrm{mg}$. of tetracycline hydrochloride, and was compared with a dose of $250 \mathrm{mg}$. of tetracycline hydrochloride itself. The lymecycline gave consistently higher blood levels and was absorbed more rapidly. At eight hours there was still a readily detectable level. Statistical analysis of the results showed that the differences found in blood levels were highly significant $(\mathbf{P}<0.01)$.

Urinary excretion of these compounds was also compared over a 24-hour period after a single dose in a number of male

TABLE II.-Serum Levels in Six Volunteers After a Single Oral Dose of $250 \mathrm{mg}$. Tetracycline Hydrochloride

\begin{tabular}{|c|c|c|c|c|c|}
\hline \multirow{2}{*}{$\begin{array}{l}\text { Subject } \\
\text { No. }\end{array}$} & \multicolumn{5}{|c|}{ Hours After Administration } \\
\hline & $\frac{1}{2}$ & 1 & 2 & 4 & 8 \\
\hline $\begin{array}{l}1 \\
2 \\
3 \\
4 \\
5 \\
6\end{array}$ & $\begin{array}{l}0 \\
0 \\
0 \cdot 32 \\
0 \\
0 \\
0 \cdot 47\end{array}$ & $\begin{array}{l}0 \\
0 \\
0.55 \\
0.35 \\
0.28 \\
0.92\end{array}$ & $\begin{array}{l}0.86 \\
0.33 \\
0.97 \\
1.32 \\
1 \cdot 02 \\
1 \cdot 10\end{array}$ & $\begin{array}{l}0.64 \\
0.73 \\
0.83 \\
1.57 \\
0.92 \\
0.94\end{array}$ & $\begin{array}{l}0.40 \\
0.49 \\
0.55 \\
1.24 \\
0.64 \\
0.55\end{array}$ \\
\hline Mean 1-6 & 0.13 & 0.35 & 0.93 & 0.94 & 0.65 \\
\hline
\end{tabular}

Tabi.8 III.-Serum Levels in Six Volunteers After a Single Oral Dose of Lymecycline Equivalent to $162 \mathrm{mg}$. of Tetracycline Hydrochloride

\begin{tabular}{|c|c|c|c|c|c|}
\hline \multirow{2}{*}{$\begin{array}{l}\text { Subject } \\
\text { No. }\end{array}$} & \multicolumn{5}{|c|}{ Hours After Administration } \\
\hline & $\frac{1}{2}$ & 1 & 2 & 4 & 8 \\
\hline $\begin{array}{l}1 \\
2 \\
3 \\
4 \\
5 \\
6\end{array}$ & $\begin{array}{l}0 \\
0 \\
0 \\
0.22 \\
0.22 \\
0.22 \\
0.22\end{array}$ & $\begin{array}{l}0.47 \\
0 \\
0.81 \\
2 \cdot 40 \\
0.30 \\
0\end{array}$ & $\begin{array}{l}1.44 \\
0.90 \\
1.44 \\
2.96 \\
1.58 \\
0.60\end{array}$ & $\begin{array}{l}1.56 \\
2.32 \\
1.21 \\
2.75 \\
1.04 \\
1.86\end{array}$ & $\begin{array}{l}0.59 \\
1.46 \\
0.60 \\
0.68 \\
1.52 \\
1.19\end{array}$ \\
\hline Mean 1-6 & 0.07 & 0.66 & 1.49 & 1.79 & 1.01 \\
\hline
\end{tabular}

TABLB IV--Recovery of Tetracycline Hydrochloride from Urine 24 Hours After Various Oral Doses in Seven Volunteers

\begin{tabular}{c|c|c|c}
\hline Subject No. & Dose & 24-hr. Excretion & $\begin{array}{c}\text { Excretion as } \\
\text { Percentage } \\
\text { of Dose }\end{array}$ \\
\hline 7 & 500 & $155 \cdot 5$ & 31 \\
8 & 500 & 67.5 & 14 \\
9 & 500 & $79 \cdot 8$ & 16 \\
10 & 500 & $63 \cdot 1$ & 13 \\
11 & 250 & $72 \cdot 0$ & 29 \\
12 & 250 & 66.9 & 27 \\
13 & 250 & $39 \cdot 9$ & 16 \\
\hline Mean 7-13 & & & 21 \\
\hline
\end{tabular}

Values expressed in $\mathrm{mg}$. of tetracycline hydrochloride.

TABLE V.-Recovery of Lymecycline from Urine 24 Hours After Various Oral Doses in Seven Volunteers

\begin{tabular}{c|c|c|c}
\hline Subject No. & Dose & 24-hr. Excretion & $\begin{array}{c}\text { Excretion as } \\
\text { Percentage } \\
\text { of Dose }\end{array}$ \\
\hline 7 & 324 & $139 \cdot 6$ & 43 \\
8 & 324 & $44 \cdot 6$ & 14 \\
9 & 324 & 53.5 & 17 \\
10 & 324 & 58.3 & 27 \\
11 & 162 & 53.6 & 33 \\
12 & 162 & 37.0 & 23 \\
\hline Mean 7-13 & 162 & & 28 \\
\hline
\end{tabular}

Values expressed in mg. of tetracycline hydrochloride volunteers (Tables IV and V). The drug was taken at 5 p.m., three and a half hours after the last meal. The percentage excretion of antibiotic in relation to dose was higher in six of seven after lymecycline than after tetracycline hydrochloride. The comparison of urinary excretion of the two drugs employed the same volunteers and thus a statistical analysis comparing the mean of the differences is valid and gives a value $P<0.02$. The greater excretion implied that there was greater absorption of lymecycline than of tetracycline hydrochloride from the alimentary tract.

\section{Clinical Trial}

On the basis of these findings it was concluded that a trial of lymecycline in patients was justified. Many of the sideeffects of tetracyclines are due to poor absorption so that residual antibiotic disturbs the alimentary flora, and a tetracycline compound which is more completely absorbed from the gut might be expected to cause fewer of these effects.

The procedure for the trial has been outlined in the section dealing with methods. The distribution of patients was very similar in the two groups. The mean age of male and female patients receiving lymecycline was 50 and 52 years, and of those in the tetracycline hydrochloride group 51 and 50 years respectively. The mean length of treatment was 7.0 days for patients on tetracycline hydrochloride and 7.7 days for patients on lymecycline. The standard dose prescribed was $250 \mathrm{mg}$. of tetracycline hydrochloride four times daily, though for a few patients an initial loading dose of $500 \mathrm{mg}$. was prescribed. Lymecycline capsules were made up identically but contained the equivalent of $162 \mathrm{mg}$. of tetracycline hydrochloride. Thus although $250 \mathrm{mg}$. of tetracycline hydrochloride was prescribed, with lymecycline the equivalent of only $162 \mathrm{mg}$. of the drug was given. The medical staff and pathologists were ignorant of which drug was being used at any time.

Indications for Therapy and Clinical Response.-Table VI sets out the main indications for which tetracycline drugs were

TABLE VI.-Conditions for Which Chemotherapy Was Given in Clinical Trial

\begin{tabular}{|c|c|c|c|c|c|}
\hline & & & & Lymecycline & $\frac{\begin{array}{c}\text { Tetracycline } \\
\text { Hydrochloride }\end{array}}{8}$ \\
\hline $\begin{array}{l}\text { Post-operative chest infectio } \\
\text { Exacerbation of chronic broo } \\
\text { Asthma }+ \text { infection } \\
\text { Pneumonia ... } . . \\
\text { Other respiratory conditions } \\
\text { Operative prophylaxis } \\
\text { Urinary infection } . . . \\
\text { Gastro-intestinal infection }\end{array}$ & $\begin{array}{r}\ddot{2} \\
\because \\
\because \\
\because \\
\because\end{array}$ & $\begin{array}{l}\because \\
\because \\
\because \\
\because \\
\cdots\end{array}$ & $\begin{array}{l}\because \\
\because \\
\because \\
\because \\
\therefore\end{array}$ & $\begin{array}{r}14 \\
10 \\
5 \\
4 \\
4 \\
16 \\
2 \\
3\end{array}$ & $\begin{array}{r}8 \\
10 \\
3 \\
4 \\
2 \\
15 \\
0 \\
2\end{array}$ \\
\hline Total patients.. & $\ldots$ & $\ldots$ & $\ldots$ & 58 & 44 \\
\hline
\end{tabular}

prescribed to patients in the trial. In all these patients a tetracycline compound was the only antibiotic employed in treatment. There were other cases in which antibiotics in addition to a tetracycline were prescribed, but these are not considered here. Except for prophylactic use, the treatment was given initially because a tetracycline was likely to be effective, and was continued if bacteriological examination had shown infection with tetracycline-sensitive organisms, or if a rapid clinical effect had been obtained. At the end of therapy its success or otherwise was assessed by a member of the clinical staff on the basis of the patient's clinical response. Of the 58 patients given lymecycline, three died and in three others the clinical response was unsatisfactory. Of the 44 given tetracycline hydrochloride three died and in one other the response was unsatisfactory. In all other patients a satisfactory clinical response was recorded.

Blood Levels.-Blood was taken from a number of patients as near as could be ascertained two hours, four hours, and in a few patients six hours after a dose had been taken during the course of treatment. The results are listed in Tables VII 
and VIII. Contrary to expectation and to the findings in volunteers the mean antibiotic levels after lymecycline were lower than those in patients receiving tetracycline hydrochloride. This was particularly marked two hours after a dose, when the level was only $50 \%$ of that found in the patients receiving tetracycline hydrochloride. Analysis by the Student t test gave values of 1.889 and 0.994 respectively for the differences in the two-hour and four-hour tetracycline levels. Thus the probability. $P$ is 0.1 or greater on both occasions and statistical analysis is inconclusive. However, it is equally necessary to be cautious before non-significance of the results can be assumed. Further comment on the findings is reserved for the discussion.

Side-effects.- So far as side-effects were concerned, however, no difference was detected between the two drugs. Table IX sets out the actual findings and numbers involved. More than one side-effect was observed in some patients, but in neither

TABle VII.-Clinical Trial. Serum Levels in Patients Treated with Tetracycline Hydrochloride

\begin{tabular}{|c|c|c|c|}
\hline \multirow{2}{*}{ Patient No. } & \multirow{2}{*}{ Indication for Therapy } & \multicolumn{2}{|c|}{ Hours after Administration } \\
\hline & & 2 & 4 \\
\hline $\begin{array}{l}1 \\
2 \\
3\end{array}$ & $\begin{array}{l}\text { Lung abscess } \ldots . \quad . \quad \ldots \\
\text { Sarcoidosis; prostatectomy } \quad \ldots \\
\text { Myocardial infarction; chest infec- }\end{array}$ & $\stackrel{1.67}{-}$ & $\begin{array}{l}1 \cdot 11 \\
1 \cdot 70\end{array}$ \\
\hline 4 & $\begin{array}{l}\text { tion } \\
\text { Subarachnoid haemorrhage; atelec- }\end{array}$ & - & $1 \cdot 25$ \\
\hline 5 & $\begin{array}{l}\text { tasis } \\
\text { Post-operative chest infection }\end{array}$ & $\begin{array}{l}2 \cdot 58 \\
2 \cdot 36\end{array}$ & - \\
\hline $\begin{array}{l}3 \\
6 \\
7 \\
8 \\
9\end{array}$ & 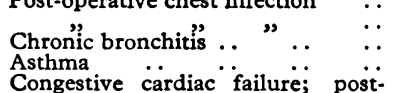 & $\begin{array}{l}2.00 \\
1.07 \\
1.06 \\
-\end{array}$ & $\begin{array}{l}\overline{\overline{0}} \\
0.99 \\
0.90\end{array}$ \\
\hline $\begin{array}{l}10 \\
11 \\
12\end{array}$ & 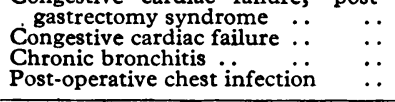 & $\begin{array}{l}5 \cdot 67 \\
2 \cdot 35 \\
2 \cdot 12\end{array}$ & $\begin{array}{l}3 \cdot 72 \\
4 \cdot 14 \\
=\end{array}$ \\
\hline Mean 1-12 & & $2 \cdot 36$ & 1.97 \\
\hline
\end{tabular}

Values expressed in $\mu \mathrm{g}$. of tetracycline hydrochloride per $\mathrm{ml}$.

Table VIII.-Clinical Trial. Serum Levels in Patients Treated with

\begin{tabular}{|c|c|c|c|c|c|}
\hline \multirow{2}{*}{ Patient No. } & \multirow{2}{*}{\multicolumn{2}{|c|}{ Indication for Therapy }} & \multicolumn{3}{|c|}{ Hours after Administration } \\
\hline & & & 2 & 4 & 6 \\
\hline $\begin{array}{l}13 \\
14 \\
15 \\
16 \\
17 \\
18 \\
19 \\
20 \\
21 \\
22 \\
23 \\
\end{array}$ & 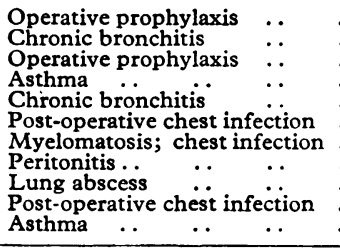 & $\begin{array}{l}\cdots \\
\cdots \\
\cdots \\
\cdots \\
\cdots \\
\cdots \\
\cdots\end{array}$ & $\begin{array}{l}1 \cdot 74 \\
\overline{-} \\
\overline{0} \\
0.80 \\
0.92 \\
\overline{1.05} \\
\overline{1.96}\end{array}$ & $\begin{array}{l}2.40 \\
1.94 \\
2 \cdot 40 \\
0.89 \\
1 \cdot 24 \\
0.74 \\
\frac{2.29}{1.11} \\
1.52\end{array}$ & $\begin{array}{l}= \\
= \\
\overline{=} \\
1.32 \\
2.54 \\
1.32 \\
0.74\end{array}$ \\
\hline Mean 13-23 & & & $1 \cdot 17$ & 1.50 & $1 \cdot 48$ \\
\hline
\end{tabular}

Values expressed in $\mu \mathrm{g}$. of tetracycline hydrochloride per $\mathrm{ml}$.

TABLE IX.-Clinical Trial. Incidence of Side-effects Among Patients Treated with Lymecycline or Tetracycline Hydrochloride

\begin{tabular}{|c|c|c|c|c|c|c|c|}
\hline & & & & & & Lymecycline & $\begin{array}{l}\text { Tetracycline } \\
\text { Hydrochloride }\end{array}$ \\
\hline \multicolumn{6}{|c|}{$\begin{array}{l}\text { Total no. of patients receiving treatment } \\
\text { Total no. of patients in whom side-effects }\end{array}$} & \multirow{11}{*}{$\begin{array}{r}58 \\
13 \\
2 \\
3 \\
5 \\
1 \\
1 \\
2 \\
2 \\
4 \\
1 \\
1\end{array}$} & \multirow{11}{*}{$\begin{array}{r}10 \\
3 \\
3 \\
2 \\
0 \\
2 \\
1 \\
1 \\
3 \\
0 \\
1\end{array}$} \\
\hline developed & & & -. & $\cdots$ & . & & \\
\hline \multirow{4}{*}{\multicolumn{2}{|c|}{$\begin{array}{l}\text { Unpleasant taste in mouth } \\
\text { Sore mouth or lips } \\
\text { Sore tongue } \\
\text { Discoloured tongue } \\
\text { Thrush }\end{array}$}} & & $\because$ & . & 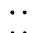 & & \\
\hline & & . & $\ddot{0}$ & $\because$ & $\because$ & & \\
\hline & & & & .. & . & & \\
\hline & . & $\ldots$ & .. & .. & . & & \\
\hline Vomiting & $\therefore$ & .. & .. & .. & .. & & \\
\hline Flatulence or & & $\cdots$ & $\cdots$ & $\cdots$ & $\cdots$ & & \\
\hline Diarrhoee . & . & . & .. & . & $\cdots$ & & \\
\hline $\begin{array}{l}\text { Pruritus ani } \\
\text { Stin rash }\end{array}$ & $\cdots$ & $\cdots$ & $\cdots$ & .. & $\cdots$ & & \\
\hline Skin rash & . & . & .. & .. & $\cdots$ & & \\
\hline
\end{tabular}

TABLB X.-Assay of the Tetracycline Hydrochloride and Lymecycline Capsules Used in the Clinical Trial

\begin{tabular}{|c|c|c|c|c|}
\hline & & Capsule 1 & Capsule 2 & Mean \\
\hline $\begin{array}{l}\text { Tetracycline hydrochloride } \\
\text { Lymecycline . . . . }\end{array}$ & $\because$ & $\begin{array}{l}279 \cdot 25 \\
150 \cdot 00\end{array}$ & $\begin{array}{l}250 \cdot 75 \\
150 \cdot 00\end{array}$ & $\begin{array}{l}265 \cdot 00 \\
150.00\end{array}$ \\
\hline
\end{tabular}

Values expressed as $\mathrm{mg}$. of tetracycline hydrochloride. group were side-effects so bad that the drug had to be discontinued on any occasion.

Assay of Capsules.-The results of assaying two capsules each of tetracycline hydrochloride and lymecycline from the stock used for the trial are shown in Table X.

\section{Discussion}

The results we have obtained fall into two categories: those from volunteers to whom both drugs were given separately at different times and serum levels or urinary excretion compared, and those from patients where only one drug was administered to any individual and only serum levels were determined. In the volunteers quite clear indications were obtained that lymecycline was absorbed more readily and gave higher blood levels than a larger dose of tetracycline hydrochloride.

In a series of four subjects Purcell et al. (1954) reported that $10-23 \%$ of a dose of $1 \mathrm{~g}$. of tetracycline hydrochloride was excreted within 24 hours. The percentage urinary excretion of a dose of tetracycline hydrochloride that we found in seven subjects varied from 13 to $31 \%$ in 24 hours, and was thus a little higher but of the same order. The percentage urinary excretion of lymecycline in the same seven subjects over the first 24 hours was appreciably greater, being 14-43\% of the dose. This implied greater absorption of lymecycline from the gut, though other explanations are possible; for instance, that excretion of lymecycline is more rapid, or that more tetracycline hydrochloride is removed by other pathways than by the renal tract.

Greater absorption of lymecycline, where direct comparison could be made, was substantiated by the blood levels found in volunteers. There was considerable variation between the levels obtained in different subjects, but those who had the highest serum levels with one drug also showed the highest levels when they received the other. In regard to individual variability of absorption, Putnam et al. (1953-4) could detect no demonstrable blood tetracycline level in 3 out of 10 subjects who received $250 \mathrm{mg}$. of tetracycline hydrochloride, and Finland and Garrod (1.960) report that $5 \%$ of individuals regularly absorb tetracycline compounds poorly.

The circumstances of the clinical trial allowed no comparison of blood levels following the administration of both drugs in the same patient. Thus no conclusion could be drawn on whether the high blood levels found in two patients (Nos. 9 and 10) who received tetracycline hydrochloride would also have been high if they had in fact received lymecycline. In fact, in comparison with the blood levels found in the other members of the tetracycline hydrochloride group, quality control methods show that the levels found in these two patients lie outside the $5 \%$ warning limits established by the remainder of the group. Also these were the only two patients in the trial in whom blood tetracycline levels were determined who were suffering from congestive cardiac failure, a condition in which renal function may be impaired. If these results are omitted as unrepresentative the mean blood levels for tetracycline hydrochloride at two and four hours become 1.89 and $1.19 \mu \mathrm{g} . / \mathrm{ml}$. respectively. Despite these reasons for regarding the results in these two patients as exceptional they cannot be ignored with certainty. In regard to the therapeutic use of lymecycline it should be noted that in a few patients in whom blood levels were determined six hours after their last dose levels as high as those obtained at four hours were found.

So far as side-effects were concerned no difference was detected between the two compounds, but as the mean duration of treatment was less than eight days any lessening of gastrointestinal side-effects as a result of greater absorption might not be expected to show, and comparisons should be made in patients receiving long-term therapy. For tetracycline McCorry and Weaver (1955) found a rather lower incidence of 
side-effects than we have recorded, but they did not record the incidence of minor oral side-effects such as sore tongue. The incidence of diarrhoea found in our study is much the same as McCorry and Weaver recorded, although much less than that found by Garrod and Waterworth (195960 ), who reported diarrhoea in 32 out of 141 patients receiving tetracycline hydrochloride.

Despite the conflict of the drug levels in the serum, which were anyhow not conclusive, the clinical trial indicated that lymecycline was an acceptable alternative to tetracycline hydrochloride judged both by therapeutic response and by the incidence of side-effects, but without having any great advantage over the latter drug.

However, there is one criticism of the compound as it is used at present which must be made. There is confusion in the Italian literature, which we have seen only in translation, over the dose of lymecycline employed in earlier studies. This has occurred because the dose has been recorded as weight equivalents to other tetracycline preparations and not to weights of the compound itself. We do not know if this.way of recording the dose is justified, but presumably it arises because, in the preparation of lymecycline, tetracycline base is the starting substance, and the final product is subsequently standardized for activity using tetracycline base or tetracycline hydrochloride as comparative standards. In fact, all lymecycline preparations have less activity than equivalent weights would lead one to expect because of additional moisture and the presence of a small percentage of inactive but non-toxic tetracycline epimers. The presence of such factors may not even be suspected if a subsequent correction back to a tetracycline standard is made, but strictly one should be aware of their presence.

Some Italian papers report the use of doses of lymecycline in tetracycline base equivalents and others in tetracycline hydrochloride equivalents; this is actually a difference of $8.2 \%$, which, when comparative studies are made, could lead to appreciable differences. To underline this confusion, in two communications clearly based on the same data de Carneri et al. (1961) refer to doses given to volunteers as equivalent to $150 \mathrm{mg}$. of tetracycline hydrochloride, and de Carneri (1961) to doses equivalent to $150 \mathrm{mg}$. of tetracycline base. In any further studies on this compound it would seem desirable that the dose employed should be recorded as the weight of the compound itself.

\section{Summary}

Serum levels and urinary excretion of lymecycline (tetracycline-L-methylenelysine; Tetralysal) and tetracycline hydrochloride were compared in volunteers. Lymecycline showed higher serum levels in relation to dose administered and a higher percentage absorption of the dose. In a subsequent clinical trial serum levels from patients showed no statistically significant difference, though levels in the tetracycline hydrochloride group were slightly higher. Therapeutic response was equally satisfactory in both groups and the incidence of side-effects was the same. It is suggested that in future work with lymecycline the dose should be recorded as the weight of the compound itself.

Our thanks are due to Dr. M. E. Solari, of Chelsea College of Science and Technology, for a statistical analysis, and to Fraser Chemicals Ltd. for supply of lymecycline and control tetracycline hydrochloride capsules for use in the clinical trial. In addition, we would like to thank the physicians and surgeons on the staff of the Queen Elizabeth Hospital, Birmingham, for their kindness in allowing us to conduct the clinical trial of this drug on patients under their care.

\section{REFERENCES}

Barber, M., and Garrod, L. P. (1963). Antibiot. and Chemother., p. 230. Bond, J. M., Lightbown, J. W., Barber, M., and Waterworth, P. M. Bond, J., M., Lightbown, J. W.,

de Carneri, I. (1961)." Communications to the 2nd International Symposium of Chemotherapy, Naples, 14-17 September 1961.

- Coppi, G., Lauria, F., and Logemann, W. (1961). Farmaco, Ed. prat., 16, 65.

and Manfredi, N. (1962). Arzneimittel.-Forsch., 12, 1174.

Finland, M., and Garrod, L. P. (1960). Brit. med. Ұ., $2,959$.

Garrod, L. P., and Waterworth, P. M. (1959-60). Antibiot. Ann., p. 440. McCorry, R. L., and Weaver, J. A. (1955). Lancet, 1, 1102.

Purcell, E. M., Wright, S. S., Mou, T. W., and Finland, M. (1954). Procell, Soc. Mright, S. Siol. (N.Y. Mou, 85, 61.
Proc.

Putnam, L. E., Hendricks, F. D., and Welch, H. (1953-4). Antibiot. Ann., p. 88 .

\title{
Controlled Comparison of Lymecycline with Tetracycline Hydrochloride in Exacerbations of Chronic Bronchitis
}

\author{
A. PINES,* M.D., M.R.C.P.ED. ; K. PLUCINSKI,* M.D. ; J. S. B. GREENFIELD,* M.B., B.S. ; \\ R. C. MITCHELL,* M.A.
}

Brit. med. F., 1964, 2, 1495-1498

The value of the tetracyclines is often diminished by distressing side-effects. Lymecycline (Tetralysal) is a compound formed of a molecule each of tetracycline, the amino-acid L-lysine, and formaldehyde. In contrast to the customarily used tetracyclines, it is claimed to be much more soluble, stable throughout physiological $\mathrm{pHs}$, and almost completely absorbed from the gut (de Carneri et al., 1961). These properties suggest important advantages for lymecycline. The gastro-intestinal disturbances so common and often so distressing with the tetracyclines should be less, and a smaller dose should be required to reach the same blood levels (de Carneri et al., 1961 ; Capraro, 1963).

We describe a double-blind trial which suggests that lymecycline possesses therapeutic advantages.

\section{Pilot Experience \\ Present Investigation}

Our interest in lymecycline was aroused by a number of instances where patients were unable to tolerate tetracycline but then took an equivalent amount of lymecycline without any trouble. During six months 41 patients were intolerant to tetracycline and in only six was there any significant disturbance when lymecycline was given later. Consequently we began a double-blind trial to compare lymecycline with tetracycline hydrochloride in patients with chronic respiratory disease who had purulent exacerbations. Including later experience, outside

* From Ware Park Hospital, Herts. 